\title{
POTENȚIALUL PRODUCȚIONAL-DESTRUCṬIONAL AL BACTERIOPLANCTONULUI ÎN ECOSISTEMUL PRUTULUI DE JOS ÎN ANII 2015-2020
}

\author{
Igor Șubernețkii, Maria Negru \\ Institutul de Zoologie, e-mail: i.subernetkii@mail.ru
}

\section{Rezumat}

Sunt prezentate rezultatele studiilor privind producția și destrucția materiei organice de către bacterioplancton, relația dintre acestea în perioada 2015-2019 în r. Prut, în limitele Republicii Moldova.

Cuvinte-cheie: bacterioplancton, producție, destrucție, coeficientul $K_{2}$.

https://doi.org/10.53937/9789975151979.16

\section{Abstract}

The results of studies on the production and destruction of organic matter by bacterioplankton, the relationship between them in the period of 2015-2019 in the Prut River, within the borders of the Republic of Moldova, are presented.

Keywords: bacterioplankton, production, destruction, $K_{2}$ coefficient.

care a fost motivul studiilor actuale. În condițiile schimbărilor climatice aceste investigații servesc la descifrarea proceselor de midrație a bioxidul de carbon.

\section{MATERIALE ȘI METODE}

Eșantionarea a fost prelevate în conformitate cu standardul national [6]. S-au determinat indicatorii cantitativi ai producției de bacterioplancton (P) și destrucția materiei organice prin legătura bacteriană (R), precum și coeficientul $\mathrm{K}_{2}$. Probele au fost prelevate în timpul anotimpurilor de creștere bacteriană (aprilie-octombrie) 2015-2020 de la 5 stații, începând de la st. Braniște (mai jos de de baraj a rezervorului Costești-Stânca) până la st. Giurgiulesti (confluenta cu fluviul Dunarea). Experiențele privind producția și destrucția bacteriană au fost efectuate pe teren în locații de prelevare.

\section{REZULTATE}

La evaluarea situației microbiologice în sectorul investigat al r. Prut, în diferite sezoane în a. 2020 (fig. 1a) și, în general pe perioadă de vegetație (fig. 2), se poate observa o corelație vizibilă între producția de bacterioplancton $(\mathrm{P})$ și destrucția materiei organice $(\mathrm{R})$ de către acest grup de organisme acvatice.

Datorită variabilității semnificative a condițiilor de viață a bacterioplanctonului în diferiți ani de cercetare, dinamica producției bacteriene în $r$. producție și destrucție a bacteriilor planctonice, 

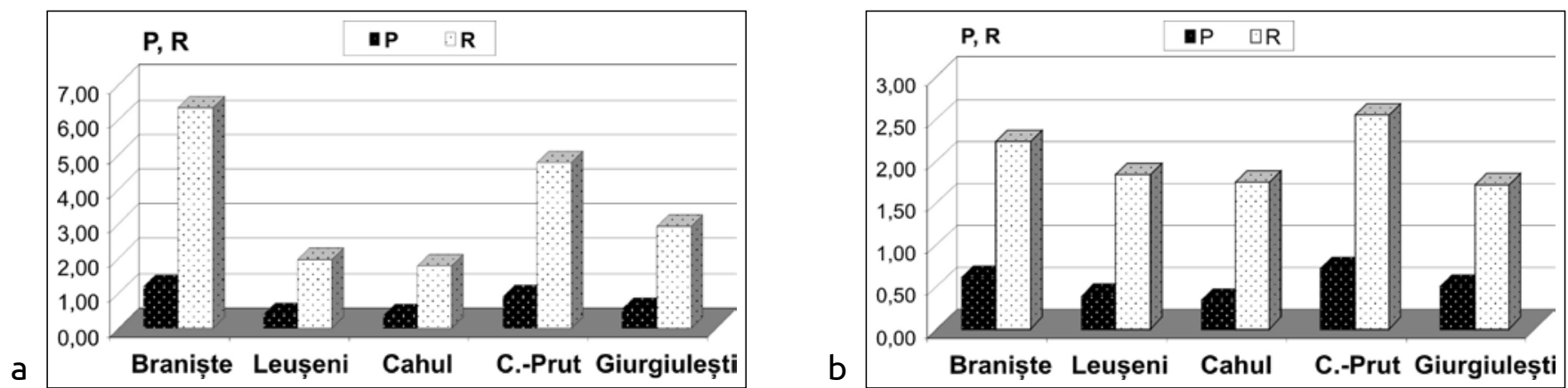

Fig. 1. Dinamica indicilior producției $(P, c a l / l)$ și destrucției $(R, c a l / l)$ zilnice în perioada de toamnă (a), și pe toată perioada de vegetație (b) în a. 2020.

Prut este, de asemenea, foarte variabilă (Fig. 2). În sezonul de vegetație din a. 2019, de exemplu, sa stabilit o creștere treptată a producției bacteriene pe cursul rîului de la st. braniște pînă la st. cahul,

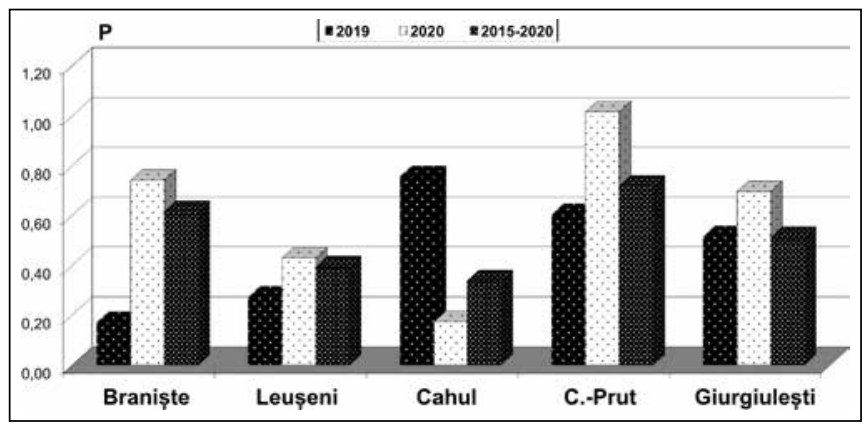

Fig. 2. Dinamica spațială a producției $(P, \mathrm{cal} / \mathrm{l})$ bacteriene zilnice în r. Prut

în diferite perioade ale anilor 2015-2020.

Indicatorii medii zilnici ai $\mathrm{P}$ și $\mathrm{R}$, pentru întreaga perioadă $2015-2020$, au fost de $0,34 \pm 0,09 \mathrm{cal} / 1$ și $1,47 \pm 0,59 \mathrm{cal} / 1$, respectiv. și o scădere treptată - pînă la st. Giurgiulești. În a. 2020, situația diferită semnificativ (Fig. 2) .

O imagine similară observată și în dinamica multianuală, a destrucției bacteriene (Fig. 3).

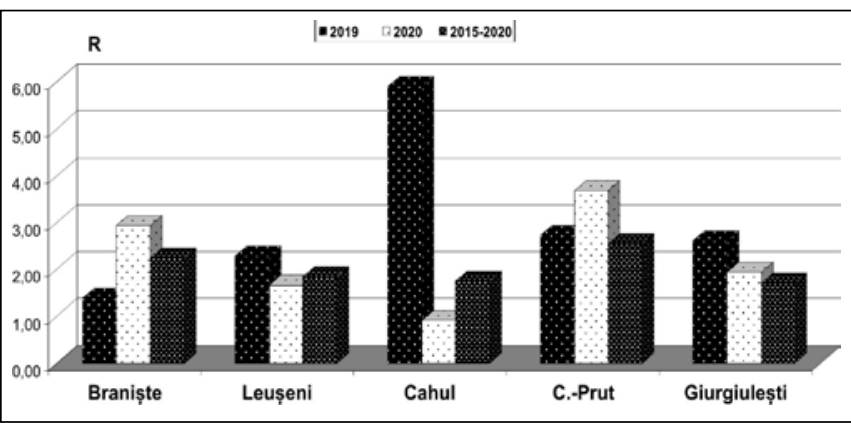

Fig. 3. Dinamica spațială a destrucției $(R, c a l / l)$ bacteriene zilnice a materiei organice în r. Prut în diferite perioade ale anilor 2015-2020.

Aspectul sezonier al activității fiziologice (productia si destructia materiei organice) a bacterioplanctonului este prezentat în tabelul 1 .

Tabelul 1. Dinamica sezonieră a principalilor indicatori ai activității bacteriene ( $P, R, c a l$ / l pe zi) în perioada de vegetație, r. Prut, anii 2015-2020

\begin{tabular}{|c|c|c|c|c|c|c|c|}
\hline \multirow{2}{*}{ Stația } & \multirow{2}{*}{ Perioada } & \multicolumn{2}{|c|}{ Primăvara } & \multicolumn{2}{|c|}{ Vara } & \multicolumn{2}{|c|}{ Toamna } \\
\hline & & $P$ & $\mathrm{R}$ & $P$ & $\mathrm{R}$ & $P$ & $\mathrm{R}$ \\
\hline Braniste & \multirow{5}{*}{$2015-2020$} & 0.44 & 0.73 & 0.76 & 2.29 & 0.65 & 3.70 \\
\hline Leușeni & & 0.39 & 1.82 & 0.48 & 1.50 & 0.32 & 2.21 \\
\hline Cahul & & 0.19 & 1.43 & 0.88 & 2.15 & 0.31 & 2.30 \\
\hline Cîșlița-Prut & & 0.77 & 2.94 & 0.78 & 1.62 & 0.61 & 3.09 \\
\hline Giurgiulești & & 0.12 & 0.59 & 0.98 & 2.16 & 0.44 & 2.40 \\
\hline
\end{tabular}

Datele prezentate, rezultă că ambii indicatori ai activității fiziologice a bacterioplanctonului cresc semnificativ în paralel cu creșterea temperaturii apei , fiind maximle în timpul verii.
În ceea ce privește coeficientul $\mathrm{K}_{2}$, care caracterizează raportul dintre materia organică produsă de bacterii și cheltuiala cu mineralizarea $\left(\mathrm{K}_{2}=\mathrm{P}\right.$ / P + R), acesta demonstrează, ca și indicatorii de 
mai sus, variază în limite mari $(0,12-0,32)$ și ajunge $(\mathrm{P}=0,95)$ primăvară la $0,21^{ \pm} 0,10$, în vara $-0,28 \pm$ 0,05 și toamna $-0,14 \pm 0,03$. În medie, pe întreaga perioadă de observație, a fost de $0,21 \pm 0,04$, care este mai mică decât cele stabilite pentru alte ecosisteme: 0,33-0,35 [4]. Cele mai mari rate sunt clasice pentru st. Braniște $-0,38$.

In ceea ce privește coeficientul $\mathrm{K}_{2}$, care caracterizează raportul dintre materia organică produsă de bacterii și cheltuiala cu mineralizarea $\left(\mathrm{K}_{2}=\mathrm{P}\right.$ / P + R), acesta demonstrează, ca și indicatorii de mai sus, variază în limite mari $(0,12-0,32)$ și ajunge $(\mathrm{P}=0,95)$ primăvară la $0,21 \pm 0,10$, în vara $-0,28^{ \pm}$ 0,05 și toamna $-0,14 \pm 0,03$. În medie, pe întreaga perioadă de observație, a fost de $0,21 \pm 0,04$, care este mai mică decât cele cunoscute în literatură: 0,33-0,35 [4]. Cele mai mari rate sunt tipice pentru st. Braniște $-0,38$.

\section{CONCLUZII}

1. Productia zilnice a bacterioplanctonului este sezonieră și variază în limitele $0,12-0,98 \mathrm{cal} / 1$, iar destructia în limitele $0,59-3,7 \mathrm{cal} / 1$.

2. Cele mai mari rate sunt caracteristice pentru st. Cahul: $\mathrm{P}=0,51(0,27-0,88) \mathrm{cal} / \mathrm{l}$ în 24 ore, $\mathrm{R}=2,6$ $(2,15-2,85) \mathrm{cal} / 1$ în 24 ore care sunt stsbilite pentru mai multe rîuri. La alte stații a râului, acesti indicatori sunt mai scăzuti- valorile $\mathrm{P}$ variind de la 0,12 pînă la $0,95 \mathrm{cal} / \mathrm{l}$ în 24 ore, iar pentru $\mathrm{R}$ - de la 0,5 pînă la $3,08 \mathrm{cal} / 1$ în 24 ore.

3. Indice $\mathrm{K}_{2}$ are valori maximale în perioadă de vară $-0,28 \pm 0,05$.
Lucrarea este realizată în cadrul proiectului 20.80009.7007.06 "Determinarea schimbărilor mediului acvatic, evaluarea migrației și impactului poluanților, stabilirea legităților funcționării hidrobiocenozelor și prevenirea consecințelor nefaste asupra ecosistemelor" (Programul de Stat 2020-2023) și a proiectelor BSB 27 și BSB 165 finanțate de Uniunea Europeană (Programul Operațional Comun "Bazinul Mării Negre 2014-2020”).

\section{BIBLIOGRAFIE}

1. KATO K. Bacteriile - o legătură între constituenții ecosistemului. Rez. Popul. Ecol. 1996. V.38, nr. 2. P.185-190.

2. ГАК Д.З. Бактериопланктон и его роль в биологической продуктивности водохранилищ. Москва, 1975, 375 с.

3. КОПЫЛОВ А.И., КОСОЛАПОВ Д.Б. Бактериопланктон водохранилищ верхней и средней Волги. Москва: Изд-во СГУ, 2008.

4. Ghid de prelevare de probe hidrochimice si hidrobiologice. Chisinău, 2015. 64p.

5. РОМАНЕНКО В.И. Микробиологические процессы продукции и деструкции органического вещества во внутренних водоемах. Л.: Наука, 1985, 296 c.

6. BELL R. T., KUPARINEN J. Evaluarea productiei de fitoplancton si bacterioplancton la începutul primăverii în lacul Erken, Suedia. Appl. Environ Microbiol. 1984. V.45. p. 1221-1230.

7. Monitoringul calitătii apei și evaluării stării ecologice a ecosistemelor acvatice. Indrumar metodic. Chișinău, 2015, 84 p. 